fully appreciated. During these years, and under Mr. Hall's leadership, the Establishment not only grew in size but also won the confidence of the aircraft industry and the Services, and its reputation as a centre for aeronautical research and development became world-wide.

In recognition of his services, Mr. Hall was created C.B.E. in 1918 and C.B. in 1937 . He was a member of the Institution of Mechanical Engineers, a fellow of the Royal Aeronautical Society, and during the years 1928-41 he served as a member of the Aeronautical Research Committee.

He had a wide and, indeed, intimate knowledge of large numbers of his staff, was a keen observer of men, and his judgment of individuals was seldom wrong. It was fitting, therefore, on his retirement in 1941, that he was retained as a consultant by the Ministry of Aircraft Production, and played a large part in recruiting the technical and scientific staffs required by the various Ministries.

Mr. Hall was a man of very wide interests; he loved fishing, was an enthusiastic bird-watcher, and a very active gardener. $\mathrm{He}$ was also a keen photographer. For many years he had interested himself in educational matters, and had been chairman of the board of governors of the Farnborough Grammar School since 1937, and was a member of the Aldershot and Farnborough Divisional Education Executive.

Mr. Hall's death will come as a shock to the large circle who came to know him through his work, and those who were privileged to know him well will realize they have lost one of the most likeable and staunchest of friends.

W. G. A. Perring

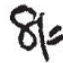

\section{Prof. W. B. Morton}

William Blarr M Mof died in Belfast on August 12 at the age of eigdy-one. He was born in Belfast, and went to stupl at the Belfast Royal Academy. After makfigulating in 1886 into Queen's College, Belfast, thenlassociated with the Royal University of Ir and, he took the B.A. degree with honours in mathefhatics in 1889 and proceeded to St. John's College, Cambridge, where he became eighth wrangler in the Mathematical Tripos of 1892. He had intended to stay in Cambridge for research, but was asked by
Everett to return to Belfast as his assistant in the Department of Natural Philosophy. He accepted the invitation and succeeded to the chair in 1897, occupying it until he retired on reaching the age limit in 1933, with a change in title to professor of physics in 1909 after Queen's College had become the Queen's University of Belfast.

Morton was above all an inspiring teacher. $\mathrm{He}$ undertook personally the greater part of the undergraduate lecturing in both mathematical and experimental physics, besides giving postgraduate courses on theoretical subjects and much appreciated public lectures. In spite of the demand this made on his time, he read widely in the history of science and in current mathematical and physical literature, and published some forty papers, mostly on the theory of electricity and hydrodynamics. His staff were usually left to develop their own lines of research, in which they received every encouragement, not least through the generosity with which he made available his large private library. His departmental duties left him little time to take part in the general administration of the University. After his retirement, however, he rendered great services as a member of the governing body and its main committees.

An appointment as a junior fellow of the Royal University of Ireland in 1894 had been followed by a fellowship in 1897 , which was continued until the dissolution of the Royal University in 1909. The connexion with colleagues in the south of Ireland was maintained after the institution of the National University of Ireland by frequent appointments until 1934 as external examiner. The visits these necessitated to Dublin, Cork, Galway and Maynooth were a source of great pleasure to him.

After the death of his wife in 1945, Morton moved from the house in which they had lived for forty years and made a long succession of colleagues and students welcome at their informal week-end gatherings. He broke up his library at the same time, giving the greater part to the Queen's University, and most of the remainder to friends. Failing health gradually restricted his activities, but until a few months before his death he continued to visit the University regularly, and to take an interest in its affairs.

K. G. Emeinus

\section{8f}

Prof. Frank Debenham, O.B.E.

Prof. Frank Debenham, who has just retired from the chair of epgopaphy at Cambridge which he was the first o hald is a descendant of an old Suffolk family. Hflook his first degree at Sydney, and it wgs as gologist, cartographer and surveyor that he why with Scott to the Antarctic. Of him it may tfary be said that he has done a great work in keeping alivelthe magnificent exploratory and scientific ideals with which Scott and his colleagues and contem: poraries faced the grim Ross Barrier in 1910 ; ideals which have indeed proved an inspiration to the succeeding generations. Thirty years have passed since Debenham was elected to a fellowship of Caius College, Cambridge, fresh from the war service which followed immediately his return from the Antarctic. Tripos examinations in geography were first held in 1920 , and he was soon busy in the new Department. In 1928 he succeeded the late Philip Lake as reader and head, in the year when the International Congress of Geography met at Cambridge. His vigorous

\section{and VIEWS}

creative powers found full scope; and by 1930, in the year of his appointment to the newly-established chair, he was planning the erection of the new building, to which his cherished project of a physiographical laboratory was added in 1938. The Cambridge school, to which Prof. J. A. Steers has just succeeded (see Nature, April 10, p. 670), may now fairly claim to have attained an international reputation; and its productivity, characteristic liveliness and happy diversity of aims undoubtedly owe much to the brisk exploratory activities and the very human sympathies of its first professor.

As teacher and expositor, Prof. Debenham's enthusiasm was infectious; and his writings reveal a much appreciated facility and clarity of expression. His recent surveys of African water problems for the Colonial Office, still in progress, have with his other work been recognized by awards of the Victoria Medal of the Royal Geographical Society, and the Livingstone Medal of the American Geographical Society; he has also received the honorary D.Sc. of 